\title{
Liisa Veenkivi in memoriam
}

Radiotoimittaja Liisa Veenkivi kuoli pitkään sairastettuaan 10. maaliskuuta 2009 Helsingissä. Hän oli 65-vuotias ja syntynyt Kemissä vuonna 1943.

Kouluvuodet Kemissä ja kesätyöt Kemijoen uitolla kirjurina tulivat usein keskusteluissa esiin lämpiminä muistoina. Kirjoitettuaan ylioppilaaksi Veenkivi lähti opiskelemaan Jyväskylän yliopistoon ja valmistui sieltä filosofian maisteriksi 1969. Toimittuaan

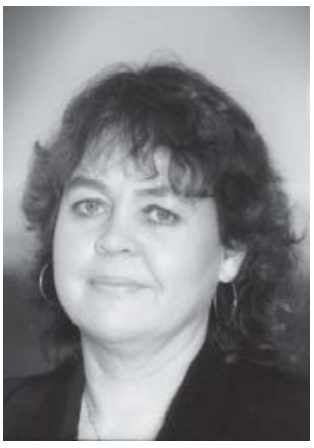
työn yhteisjärjestön pääsihteeri Timo Toiviainen. Hänen kanssaan Veenkivi teki viimeiseksi jääneen radio-ohjelmansakin.

Monissa elämänkatsomustietoa ja filosofiaa käsittelevissä radiosarjoissa Veenkiven keskustelukumppanina oli filosofi Juha Varto. Kun ohjelmia ei kuuntelijatoiveista huolimatta voinut lähettää loputtomiin uusintoinakaan, Veenkivi ja Varto toimittivat suosituimmista teemoista kirjat. Tampereen ylihistorian ja kirkkohistorian opettajana hän ryhtyi tekemään radio-ohjelmia Keski-Suomen maakuntaradioon. Hyvät työnäytteet auttoivat häntä saamaan paikan Helsingissä Yleisradion opetusosaston aikuisopetustoimittajana vuonna 1976.

1970-luvulla puhuttiin vielä Yleisradion kansansivistystehtävästä ilman ironisia äänenpainoja, ja opetusohjelmien määrä niin radiossa kuin televisiossakin kasvoi. Veenkivi ryhtyi toimittamaan jokalauantaista Aikuiskoulutuksen palveluradiota sekä muita aikuiskoulutuksen ajankohtaisohjelmia. Palveluradioita lähetettiin lopulta lähes tuhat kappaletta.

Vähitellen tehtäväkenttä laajeni. Vapaan sivistystyön yhteisjärjestön jokakesäiset Meeting in Finland -seminaarit saivat hänestä vakituisen raportoijan. Järjestön pääsihteerin Helena Kekkosen kanssa Veenkivi teki myös useita rauhankasvatussarjoja. Vuonna 1984 hänen muusikko Pelle Miljoonan kanssa tekemänsä lähetys voitti kansainvälisessä radio- ja televisio-ohjelmien Japan Prize -kilpailussa Maeda-palkinnon.

Ohjelmantekomatkat ulottuivat yhä pitemmälle, muun muassa Intiaan sekä Bhutaniin. Kotimaassa Veenkiven työn painopiste siirtyi yhä enemmän pohdiskeluihin, jotka koskivat ihmisen hyvän elämän edellytyksiä.

Veenkivi pohti ohjelmissaan jatkuvasti, millainen on se ihminen jota varten koulutusta ja yleensäkin sivistystyötä suunnitellaan. 1990-luvun lamavuosina hänestä tuntui yhä enemmän siltä, että koulutuksen rooli on johdettu vain talouden ja työelämän vaatimuksista. Usein hänellä oli keskustelukumppaninaan näissä pohdinnoissa jo Jyväskylänaikainen opiskelutoveri, Vapaan sivistys- opisto kustansi niitä yhteensä viisi. Lisäksi Veenkivi kirjoitti päätyönsä ohessa kolme teosta: Ihminen tehtävänä, Elämän ja kuoleman kehät sekä Tunnista pelkosi - tunne itsesi.

Liisa Veenkiven positiivisuus, kyky myötäelämiseen sekä huumorintaju auttoivat häntä kontaktin saamisessa keskustelukumppaniin. Hän yhdisti työssään myös ylevän ja arkisen mieleen jäävällä tavalla. Jossain kansainvälisessä konferenssissa sanoin, että meidän täytyy aloittaa aikaisin aamulla kokousmateriaalin läpikäyminen ennen ohjelmantekoa. "Aloitetaan ennen sianpieremää”, Liisa totesi. - "Milloin siis?” - "Meilläpäin se on ennen viittä”.

\section{Jaani Viherluoto}

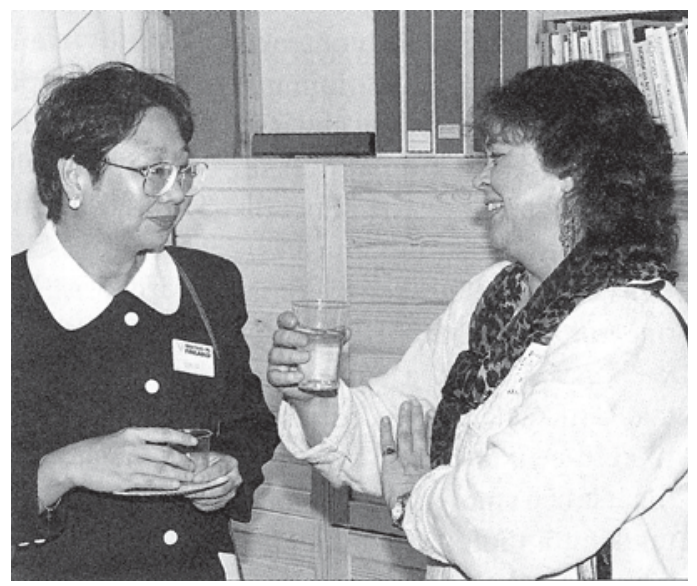

Liisa Veenkivi oli vapaan sivistystyön piirissä aina rakastettu ja mieluisa mukanaolija. Kuvassa Liisa seurustelee EAEA:n Helsingin toimiston avajaisissa singaporelaisvieraan kanssa. Kuva: Kalevi KeskiKorhonen. Kansanvalistusseuran kuva-arkisto 